Ankara Üniversitesi Türk İnkllâp Tarihi Enstitüsü Atatürk Yolu Dergisi S35-36, Mayıs-Kasim 2005, s. 435-458

\title{
Mustafa Kemal Paşa Tarafindan Ali Fuad Paşaya Gönderilen Bazı Telgraf, Tebliğ ve Yazışmalar-(II) \\ Mustafa TOKER*
}

$$
\begin{aligned}
& a
\end{aligned}
$$

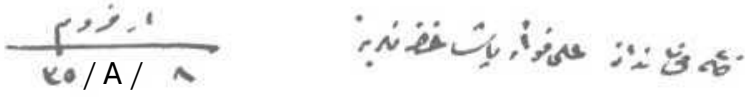

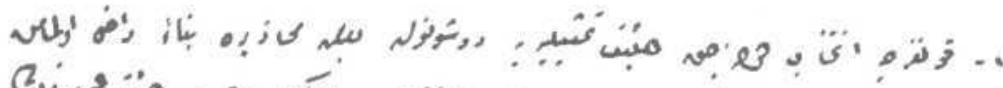

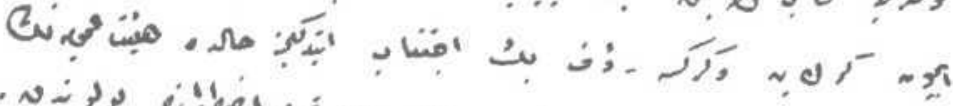

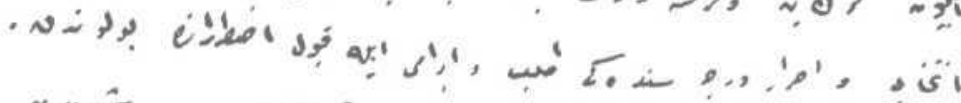

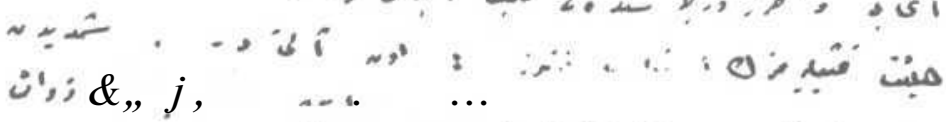

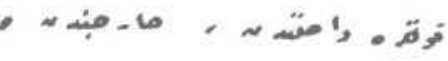

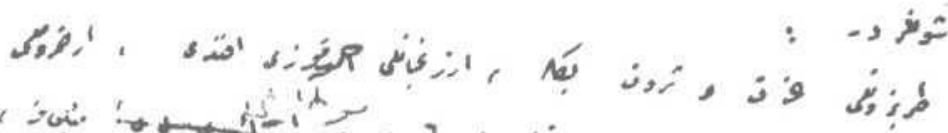

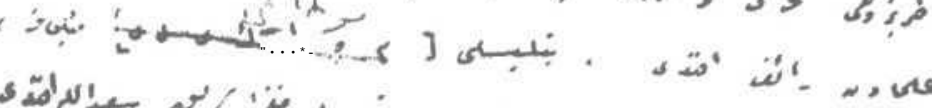

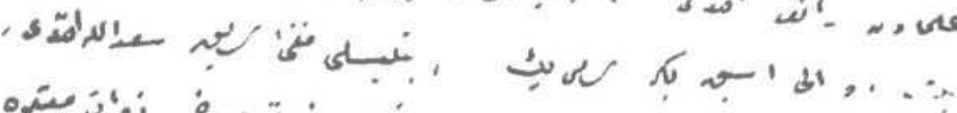

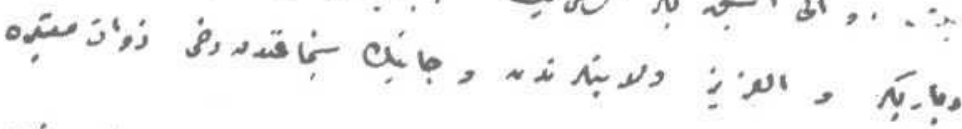

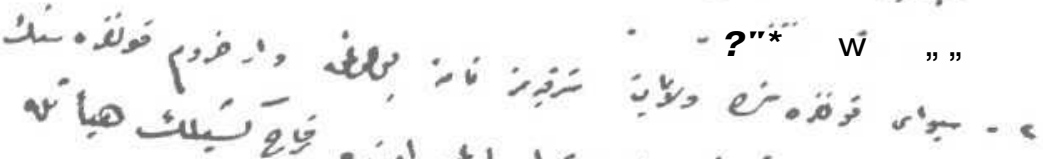

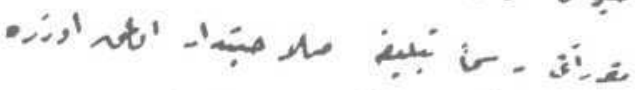

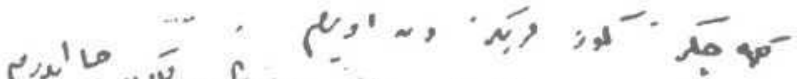

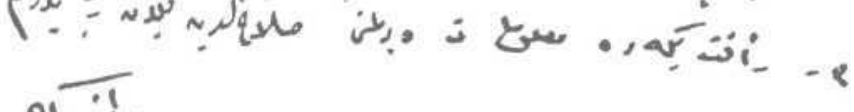

$$
\begin{aligned}
& \text { si ive }
\end{aligned}
$$

"Ankara Üniversitesi Türk İnkılâp Tarihi Enstitüsü Uzmanı. 
Şifre hâili

Erzurum $8 / 8 / 35$

20. K. Kumandanı 'Alî Fùâd Pâşâ Hazretlerine

1-Kongrece intihâb olunacak hey^et-i temsîliyeye düşünülen ba'zl mahâzîre binâ^en dahîl olmamak için gerek ben ve gerekse Ra^uf Bey ictinâb ettiğimiz hâlde hey^et-i 'umûmîyenin intihabı ve ısrar derecesindeki taleb ve ibramı ile kabûl-i ıztırârında bulunduk. Hey^et-i temsîliyemizin a'zâsı dokuz : on altıdır. Şimdiden kongre dâhilinden, hâricinden ve kongre kararıla intihâb olunan zevat şunlardır:

Trabzonlu İzet ve Servet Beyler, Erzincanll Âhmed Fevzi Efendi, Erzurumlu 'ulemâdan Raif Efendi, Bitlisli Mutkulu Hacı Mûsâ Bey, Vâlî-i Esbak Bekîr Sâmî Bey, Bitlisli Müfti-i Sabık Sa 'dullah Efendi, Diyârbekir ve El-'Azîz vilâyetlerinden ve Cânîk Sancağı'ndan dahî zevât-ı mu'tebere derdest-i intihâbdır.

2-Sivâs Kongresi'nde vilâyât-ı şarkîyemiz nâmına bulunmak ve Erzurum Kongresi'nin mukarrerâtını resmen tebliğe selâhiyetdâr olmak üzere birkaç kişilik heybetle geleceğiz. Gözlerinizden öperim.

3-RefetBeye de ma'lûmât verilmesini Selâhad-dîn Beyden rica ederim.

Mustafâ Kemâl ${ }^{1}$ 
MUSTAFA KEMAL PAŞA TARAFINDAN ALI FUAD PAŞAYA

437

$\frac{s^{\prime}-x}{x_{0} / a / \varepsilon}$

تصنئi

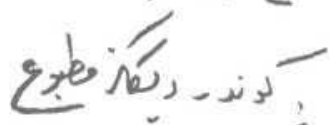

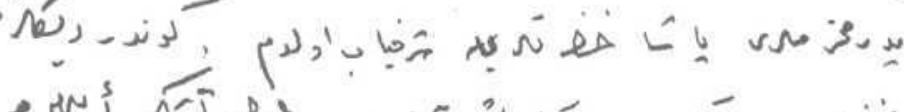

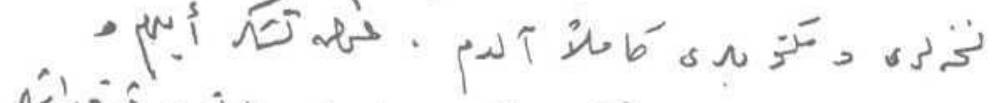

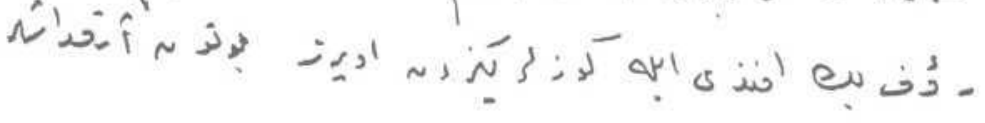

$\longrightarrow$ Uitere

- jلs ivenges
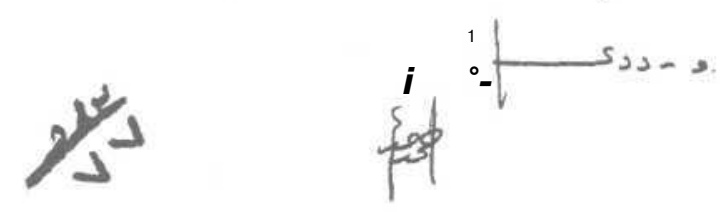
Şifre hâili

Sivas 4/9/35

\section{Ankara 20. K. Kumandanlı̆̆ına}

Peder- $i$ muhteremleri pâşâ hazretleriyle şeref-yâb oldum. Gönderdiğiniz matbu' nüshalarl ve mektûbları kamilen aldım. 'Arz-l teşekkür eylerim.

$R a^{\wedge} \hat{u} f$ Beyefendi ile gözlerinizden öperiz bütün arkadaşlar 'arz-l ta'zîmât eylerler.

Vürûdu $5 \operatorname{minh}$

Numro 77

Mustafâ Kemâl ${ }^{2}$ 
MUSTAFA KEMAL PAŞA TARAFINDAN ALİ FUAD PAŞAYA

439

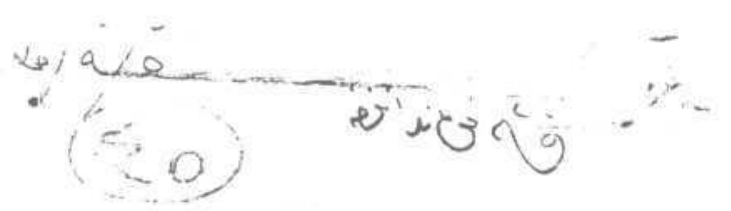

(n)

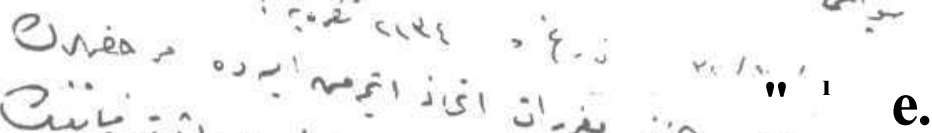

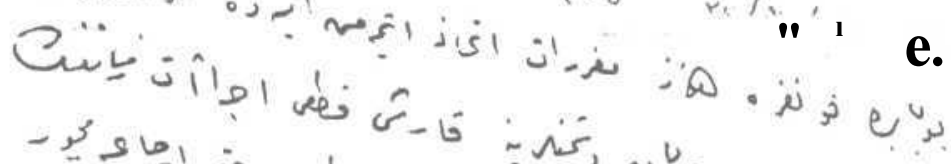

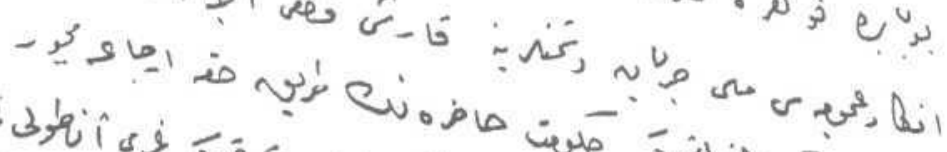

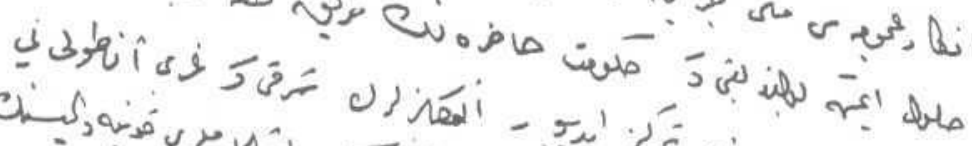

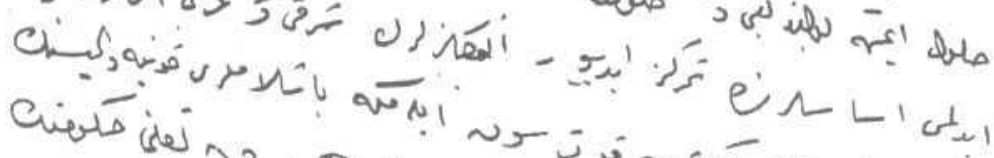

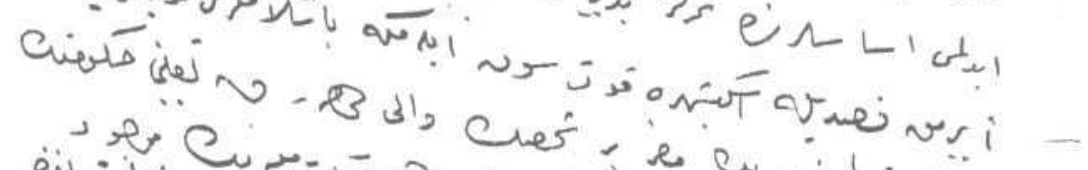

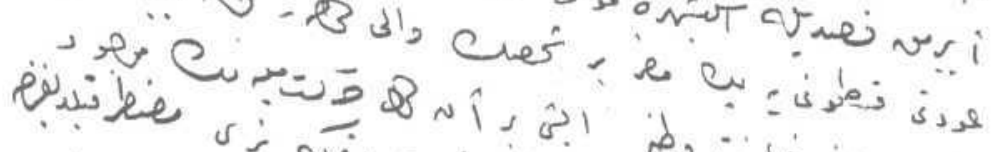

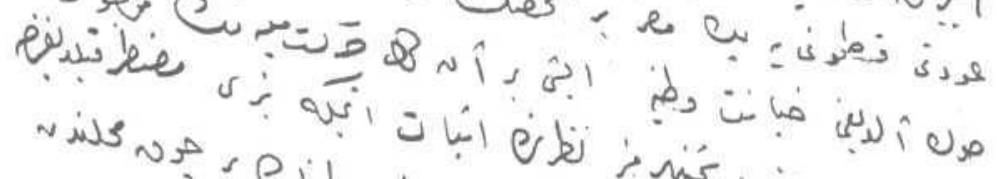

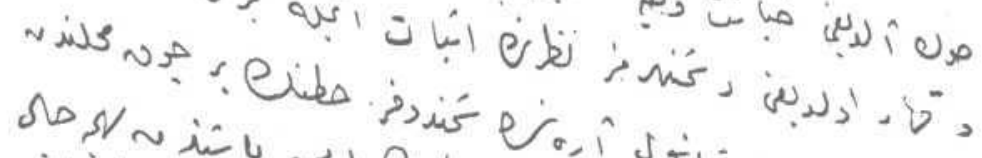

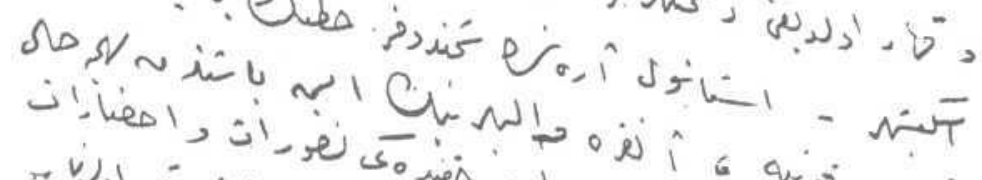

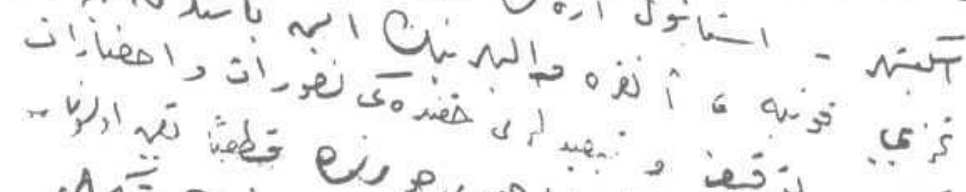

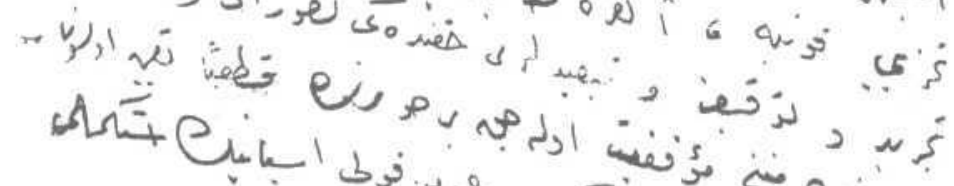

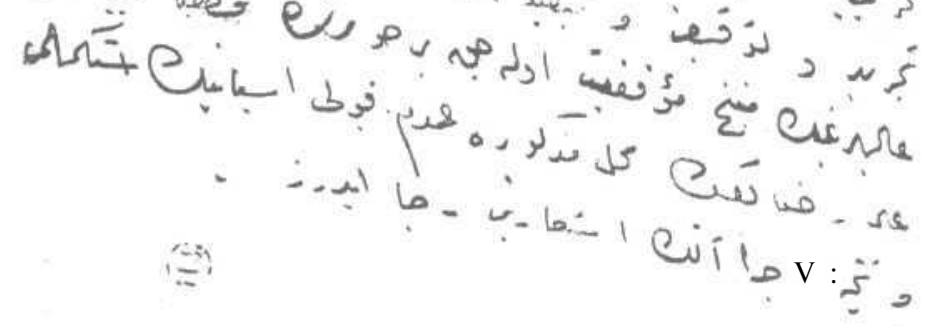


यग

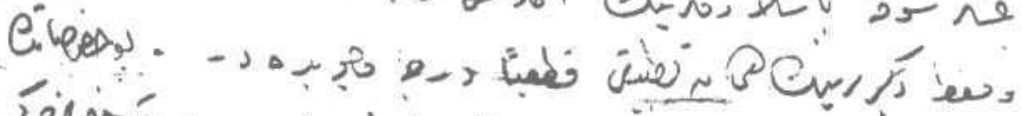

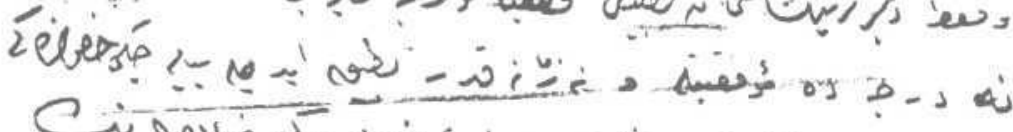

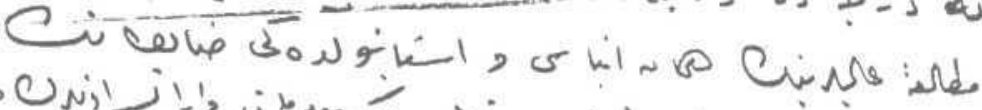

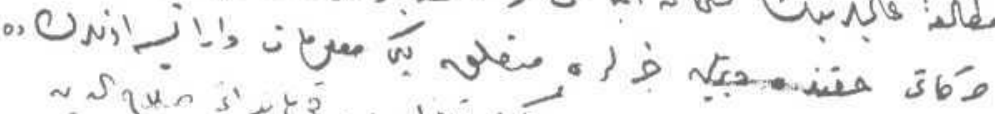

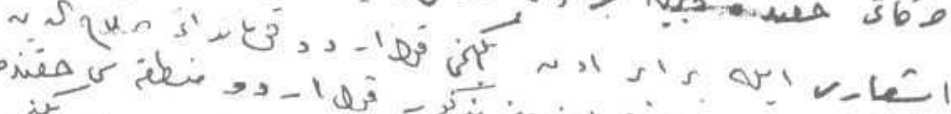

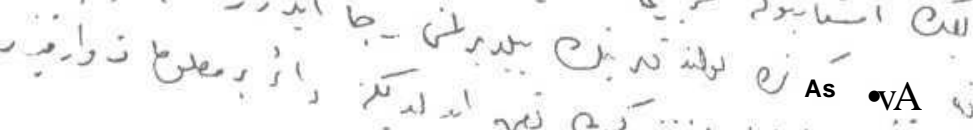

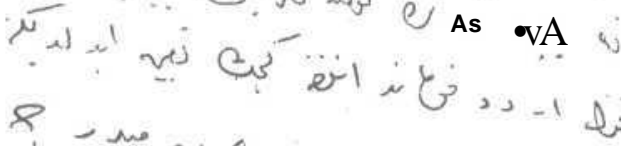

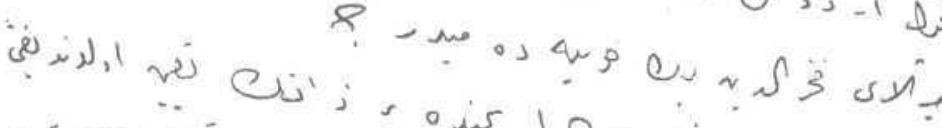

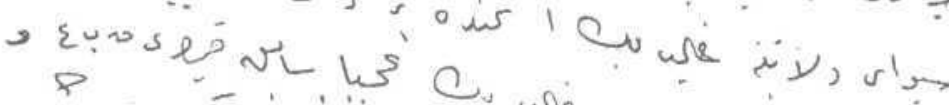

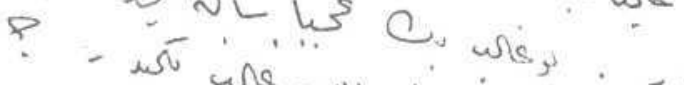

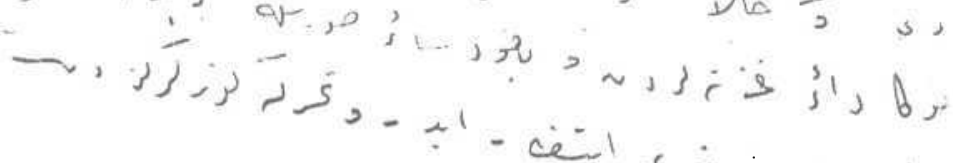

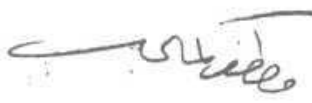

r/JVi. st 
Sivas

Vürûdu 5/9/35

\section{K. Kumandanlığına}

C. 4/9/35 târîh ve 2134 şifrey:

Bu bâbda kongre henüz mukarrerât ittihâz etmemiş ise de murahhasların efkâr-l 'umûmîyesi millî cereyan düşmanlarına karşı kati icrâât zamanının hulul etmiş bulunduğu ve hükûmet-i haziranın tarîk-i hakka ircâ'a mecbur edilmesi esâslarında temerküz ediyor. İngilizlerin şarkî ve garbi Anadolu'yu ayırmak kasdıyla Eskişehir'e kuvvet sevk eylemeğe başlamaları Konya valisinin 'avdeti Kastamonu'ya pek muzır bir şahsın vâlî olarak ta'yini hükümetin son aldığı hlyânet-i vataniye işi bir an evvel hareket-i milliyenin mevcûd ve kahhâr olduğunu düşmanlarımız nazarında

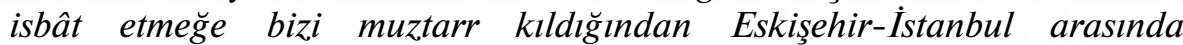
şimendûfer hattının bir çok mahallinden tahribi Konya, Ankara valilerinin is başından behe-ma-hâl tecrîd ve tevkifve teb İdleri hakkındaki tasavvurât ve ihzârât-ı 'âlîlerinin. . muvaffakıyyet olacak bir surette katiyen ta'yîn olunan 'Alî Rızâ Beyin mahal-i mezkûre 'adem-i kabulü esbabının istikmâlî ve netice-i icrââtın iş'ârını rica ederiz.

Muvafik görüldüğ̈̈ hâlde demiryolu köprülerinin tahribi İngilizlerin 'asker şevkine başladıklarının anlaşılması zamanına kadar te"hîr olunabilir. Ve fakat diğgerlerinin hemân tatbikî katiyen derece-i vücûbdadır. Bu husûsâtın ne derecede muvaffakıyyetle ve ne zamana kadar tatbik edilebileceği husuŝsundaki mütâla'a-i 'âlîlerinin hemân inbâst ve İstanbul'daki zâbitânın harekâtı hakkında verilen haberlere müte'allik yeni malûmat var ise onların da iş'ân ile beraber Onikinci. Kolordu Kumandanı Selâhad-dîn Beyin İstanbul'a 'azimeti üzerine mezkûr kolordu mintıkası hakkında ne yapmak fikrinde bulunduklarının bildirilmesini rica ederiz. OnikinciKolordu kumandanlı̆̆ına kimin ta'yîn edildiğine dâir bir malûmat var midır? Miralay Fahreddîn Bey Konya'da mıdır?

Sivas Vilâyetine Gâlîb Bey isminde bir zâtın ta yîn olduğunu ajanslar yazıyor. Bu Gâlîb Bey 'acebâ sabık Kayseri $k b a v d y$ ve hâlen Ma'mûretül- 'Aziz Vâlîsi Gâlîb Bey midir? Buna dâir gazetelerden ve yahûd sâlr suretle bir haber alındı mı? Cevâb-ı 'âlîlerine şimdi intizâr eder ve tahassürle gözlerinizden öperiz.

Mustafâ Kemâl ${ }^{3}$

${ }^{3}$ TİTE Arşivi, Kutu No:302, Gömlek No:56, Belge No:56, 56-1. 
442

MUSTAFA TOKER

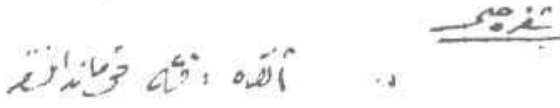

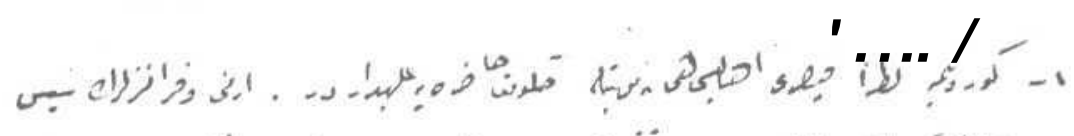

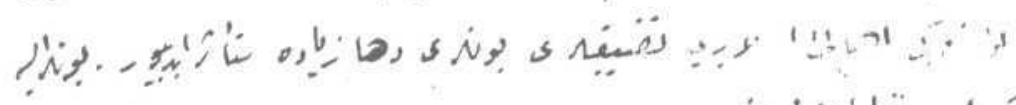

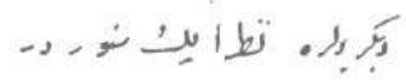

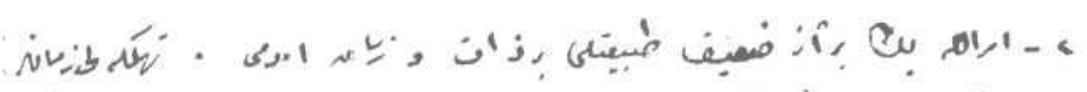

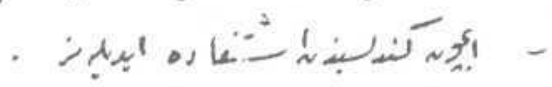

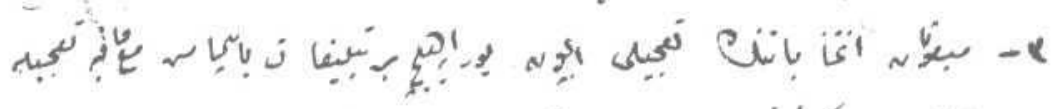

C6

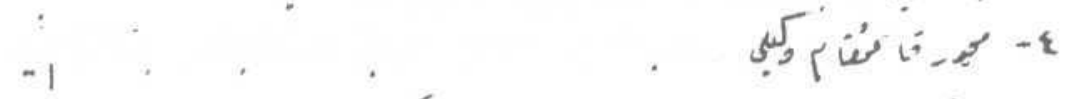

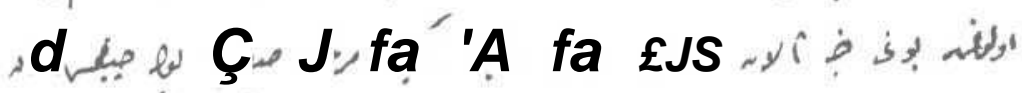

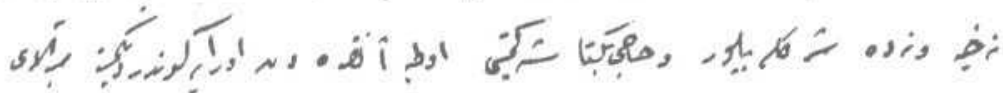

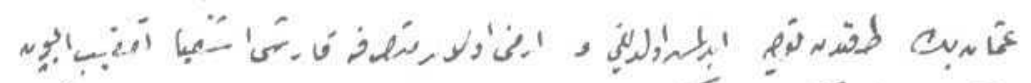

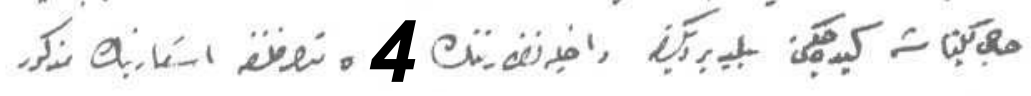

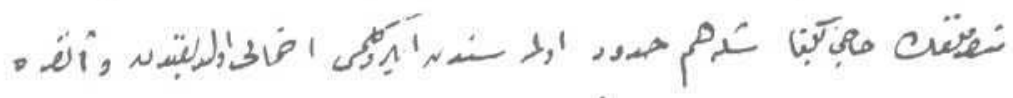

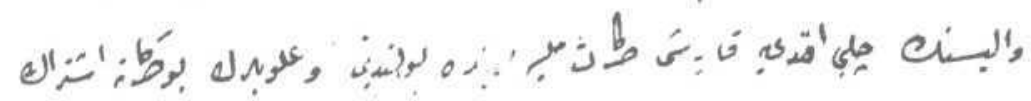

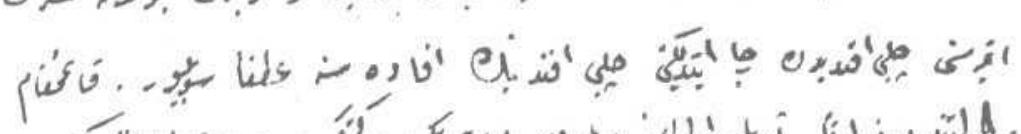

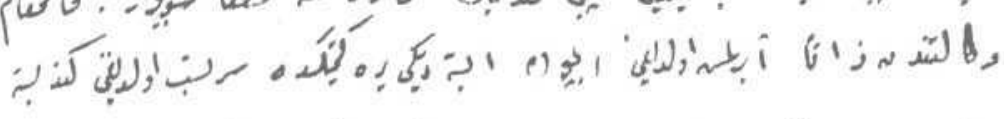

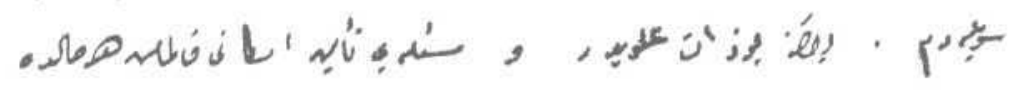


MUSTAFA KEMAL PAȘA TARAFINDAN ALİ FUAD PAŞAYA.....

443

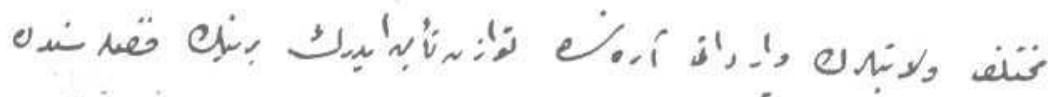

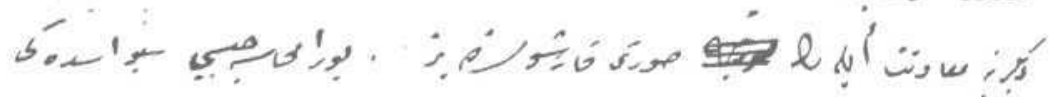

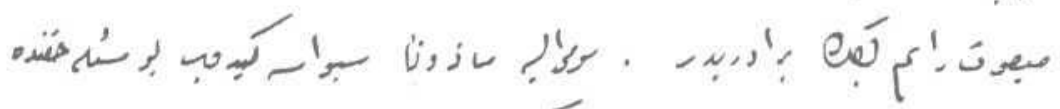

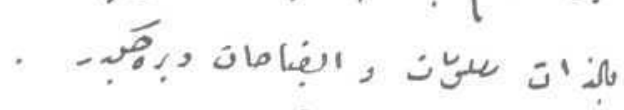

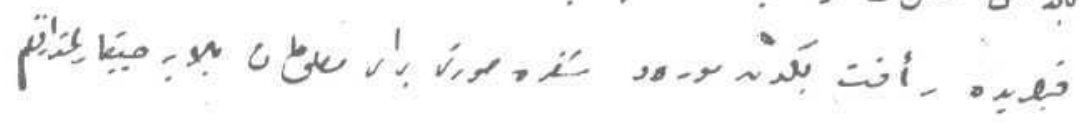

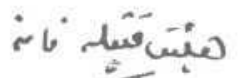
coliever

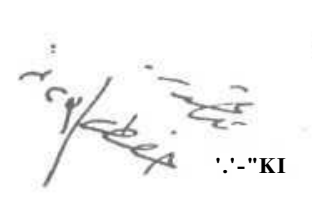


Şifre Hâili

Sivas

$23 / 9 / 35$

Ankara:20. K. Kumandanlı̆̆ına

1- Gördüğüme nazaran Kayserî ahâlîsi hemân 'umumiyetle hükûmet-i hâzıraya 'aleyhdârdır. Ermeni ve Fransızların Sîs Livası 'ndaki âhâlî-i İslâmiyeyi tazyîkleri bunları daha ziyâde müte^essir ediyor. Bunlar ise diğerlere nazaran pek münevverdir.

2- Emrullah Bey biraz za'îf tabî'atlı bir zât ü zemân adamı. Tehlikeli zamanlar için kendisinden istifâde edilemez.

3- Meb'ûsân intihâbâtının ta'cîlî için buraya hiçbir tebligat yapılmamış ma'-mâfih ta'çile başladılar. Diğer taraflarda da henüz bir tebligat yapılmadı̆̆ $l$.

4- Mucur Kâlmakâm Vekili Sâmî Bey bir zât evvelce İstanbul'dan bir kaimakâm ta'yîn olunmuş bunu haber alan mûmâ-ileyh bir mevki' te mîni fikriyle murahhas sifatıyla yola çıkmış elinden ne hayr ve ne de şer gelebiliyor. Ve Hacıbektaş'a gitmesi evvelce Ankara'dan oraya gönderdiğimiz Mîrâlây 'Osman Bey tarafindan tavsiye edilmiş olduğu ve Ermem olan mutasarrıfa karşı eşkıya ta'kîb için Hacıbektaş'a gideceğini bildirdiğ̈inden Dâhiliye Nezâretinin Niğde Mutasarrıflı̆̆ına iş'arının mezkûr mutasarrıflığın Hâcıbektâşla hem hudûd olmasından ileri gelmesi ihtimâli olduğundan ve Ankara valisinin Çelebì Efendiye karşı harekât-ı milliye 'aleyhinde bulunduğu ve 'Alevîlerin bu harekâta iştirak etmemesini Çelebì Efendiden rica ettiğini Çeleb̂̂ Efendi'nin ifâdesine 'atfen söylüyor. Kâsimakâm vekâletinden zaten ayrılmış olduğu için istediğ $i$ yere gitmekte serbest olduğunu kendisine söyledim. Yalnız bu zât 'Alevidir ve mes^eleyi te^mîn imkânı kalmamış her hâlde muhtelif vilâyetlerin varidatı arasında tevazün te^mîn ederek birinin fazlasindan diğerine mu'âvenet eylemek sureti karşısındayız. Bura muhasebecisi Sivas'daki Meb'ûs Râsim Beyin biraderidir. Mûmâ-ileyh me^zûnen Sivas'a gidib bu mes^ele hakkında bizzat ma'lûmât ve îzâhâtverecektir.

Kayseri'de Re^fet Beyden mevrûd şifre sureti berâ-yı ma'lûmât bâlâya çıkarılmıştır. Efendim.

Cevap verilmiştir. Hifz $123 \mathrm{minh}$

Hey"et-iTemsile Nâmina

Mustafâ Kemâl ${ }^{4}$

${ }^{4}$ TİTE Arşivi, Kutu No:306, Gömlek No:1, Belge No:1. 


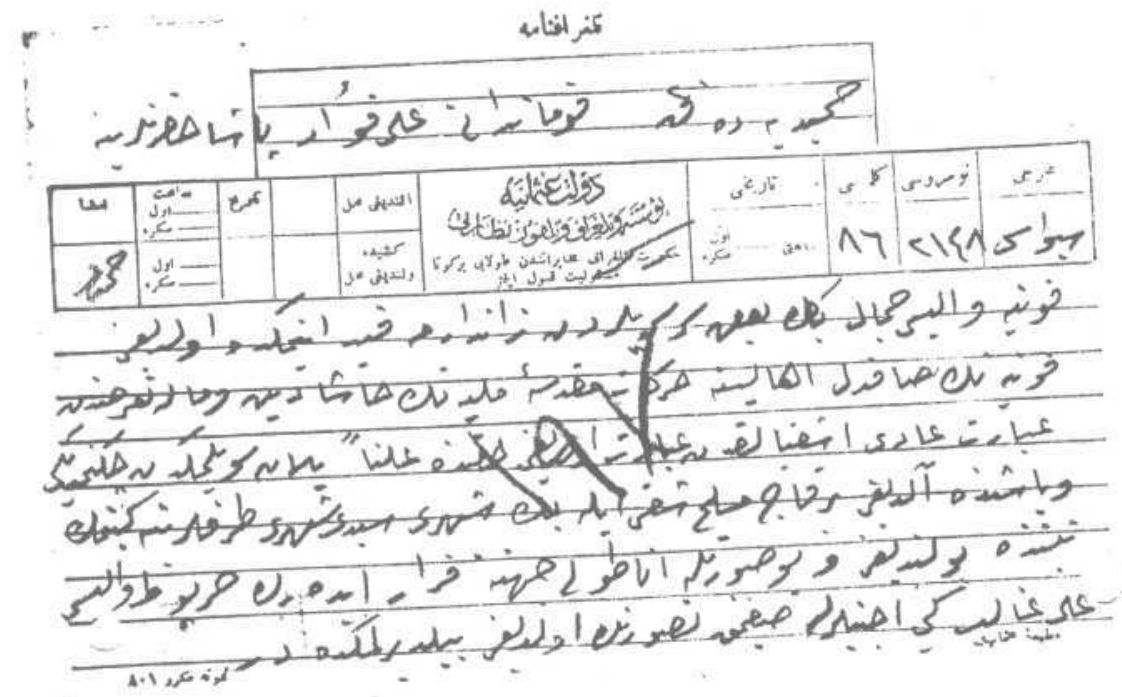

-

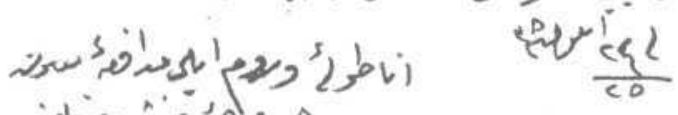
itisingisin? Príse

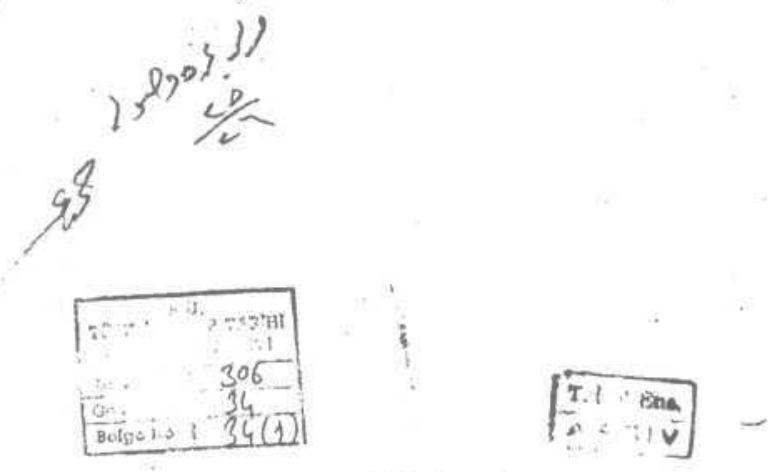
$114 / 1-2 x \circ 5$ 


\section{Telgrâfnâme}

Mahreci: Sivas

Numrosu:2148

Hamîdiye'de 20. K. Kumandanı 'Alî̌üâd Pâşâ Hazretlerine

Konya Valisi Cemâl Beyin ba 'zl serserilerden jandarma kayd etmekte olduğu Konya'nın sâf-dil ahâlîsine harekât-ı mukaddese-i milliyenin hâşâ dîn ve mala ta 'arruzdan 'ibaret 'âdî eşklyalıktan 'ibaret olduğu hakkında 'alenen yalan söylemekten çekinmediği ve başında(?) aldiğı birkaç müsellah şakî ile Beyşsehrî Seydîşehrî taraflarına gitmek niyetinde bulunduğu ve bu suretle Anadolu cihetine firar ederk Harpût Vâlîsi 'Alî Gâlîb gibi ecnebilerle sı̆̆ınmak tasavvurunda olduğu bildirilmektedir.

Keyfiyetin tahkik ve iş'ân ve tedâbîr-i kanunun ittihâzı 'arz olunur.

24/25Eylül35

Merkezimizevusulü 25/26

Anadolu ve Rumeli Müdâfa 'a-i HukukCem 'iyeti

Hey"et-iTemsîliyesiNâmına

Mustafâ Kemâl

${ }^{5}$ TİTE Arşivi, Kutu No:306, Gömlek No:34, Belge No:34. 
MUSTAFA KEMAL PAŞA TARAFINDAN ALİ FUAD PAŞAYA . . . 447

$-\mathrm{V}$

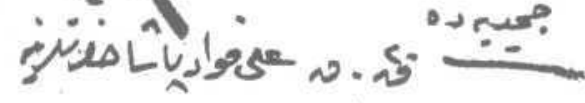

cêे $v_{0} / a / t=2$

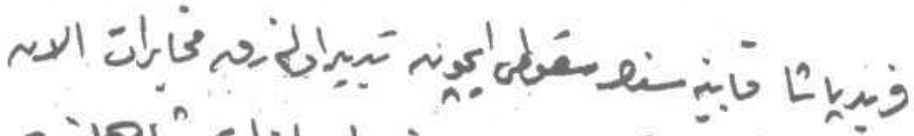

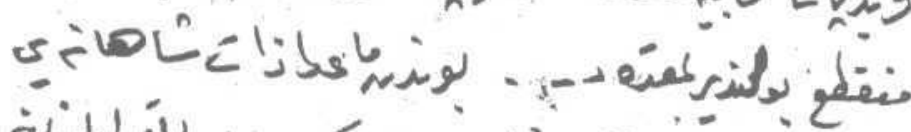

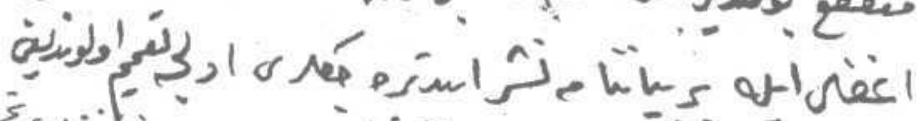
صن

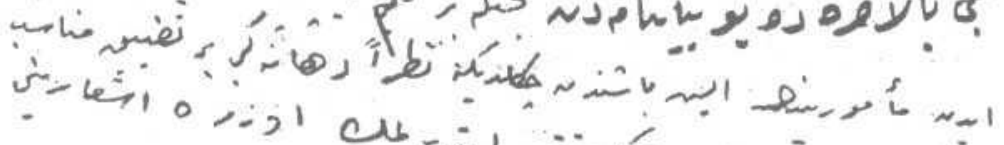
in

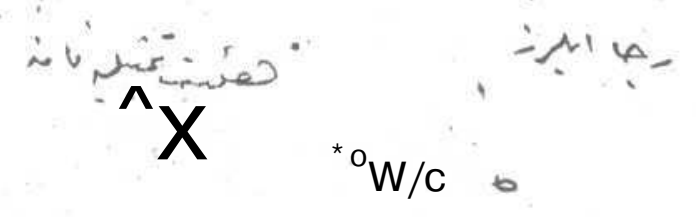

-3i-

N'N' 
Sivas

Hamîdiye'de 20. K. K. 'AlîFûâAPâşâ Hazretlerine

\section{C.:20-21/9/35şifreye}

Ferîd Pâşâ kabinesinin sükûtu için tedbir olunarak muhâberât elan münkati' bulundurulmakdadır. Bundan mâ-'adâ zât-l şahaneyi igfâl ile bir beyânâme neşr ettirecekleri evvelce ta 'mîm olunduğu gibi bil-âhire de bu beyânâmeden bahisle bir ta'mîm yapıldı. Hiyânetleri tahakkuk eden me^mûrînin iş başından çekildiğine nazaran daha ne gibi bir tazyîk-i münâsib mütâla 'a olunuyorsa tezkir ve takarrür ettirilmek üzere iş 'arını rica eyleriz.

Hey^et-i Temsîliye Nâmina

Mustafâ Kemâl

3. K. Kumandanı

Selâhaddîn ${ }^{6}$ 


$$
\begin{aligned}
& \infty
\end{aligned}
$$

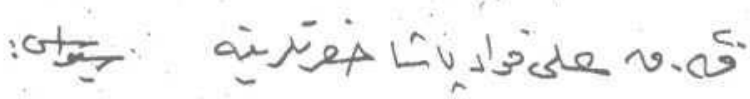

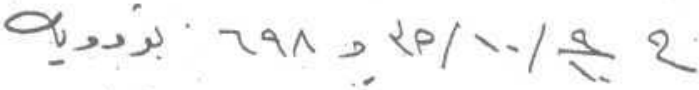

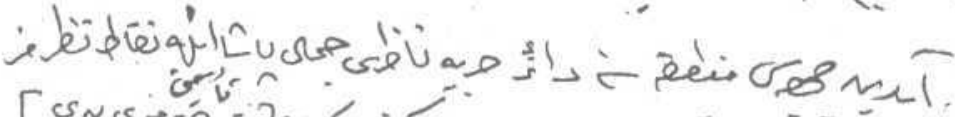

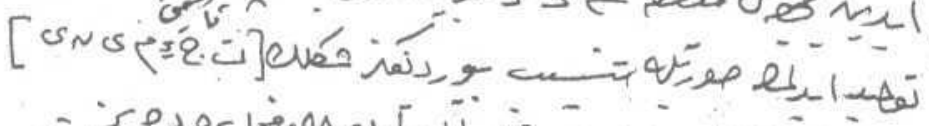

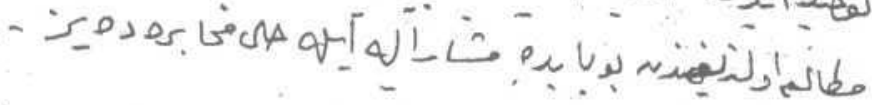

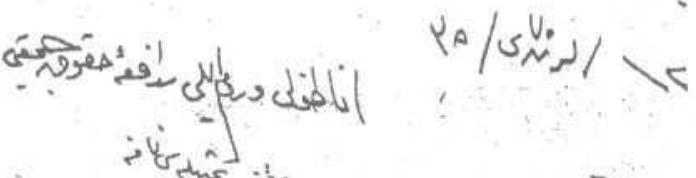
5,10

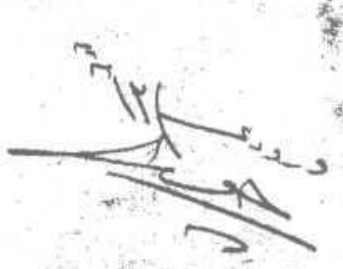


20. K. K. 'AlîFûâd Pâşâ Hazretlerine

Sivas

C.9-10110135ve698numroya

Aydın Cephesi mıntıkasına dâ"ir Harbiye Nâzın Cemâl Pâşâ ile nikkât-i nazarımız tevhîd edilmek suretiyle tensîb buyurduğunuz şeklin te^mîni mütâla'a olunduğundan bu bâbda müşârun-ileyh ile hâl-i muhaberedeyiz.

Netice 'arz olunacaktır.

12 Teşrîn-i Sani 35

Vürûdu 13 minh

Anadolu ve Rumeli Müdâfa 'a-i Hukûk Cem 'iyeti

Hey^et-iTemsîlesiNâmina

Mustafâ Kemâl ${ }^{7}$

${ }^{7}$ TİTE Arşivi, Kutu No:312, Gömlek No:55, Belge No:55. 


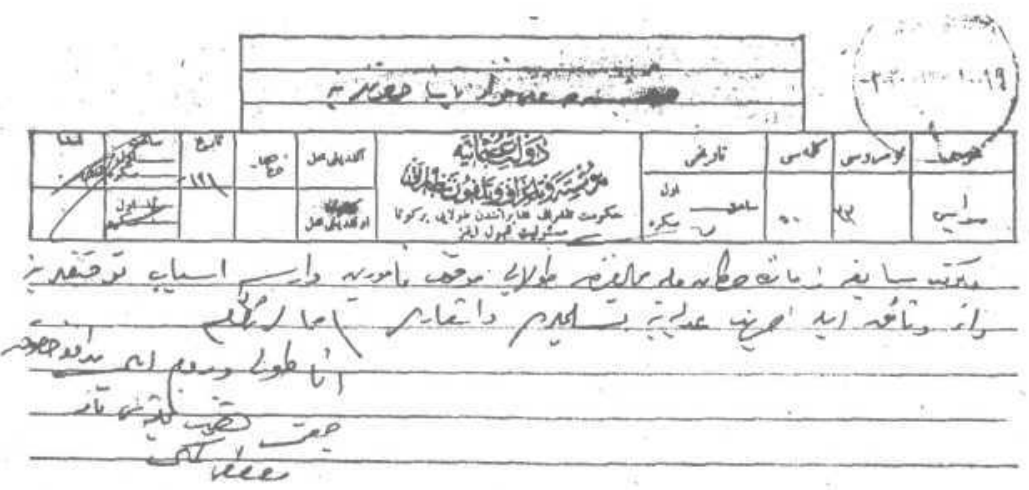




\section{Telgraf}

Sivas

\section{'Alî Fûầd Pâşâ Hazretlerine}

Hükûmet-i sabıka zamanında harekât-ı milliye muhalefetten dolayı mevkufme^mûrîn varsa esbâb-ı tevkiflerine dầ ir vesâ ${ }^{\wedge}$ ik ile cihet- $i$ 'adliyeye teslimleri ve iş 'ân.

15 Teşrîn-i Evvel 35

Anadolu ve Rumeli Müdâfa 'a-i HukukCem 'iyeti

Hey^et-iTemsîlesiNâmina

Mustafâ Kemâf

${ }^{8}$ TİTE Arşivi, Kutu No:309, Gömlek No:27, Belge No:27. 
MUSTAFA KEMAL PAŞA TARAFINDAN ALİ FUAD PAŞAYA

453

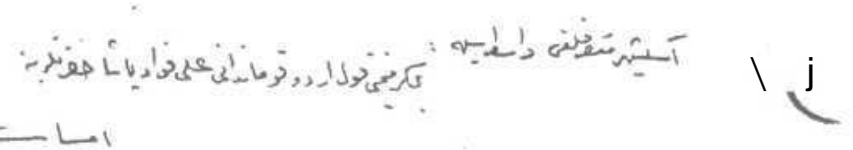

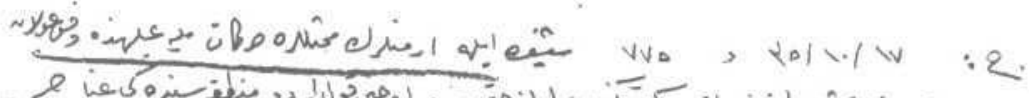
le ie

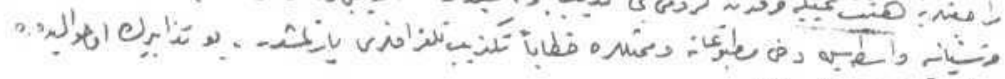

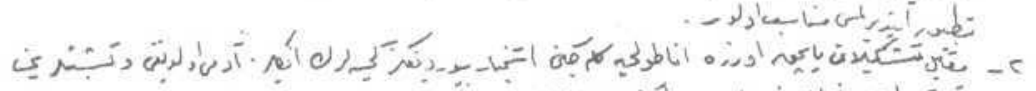

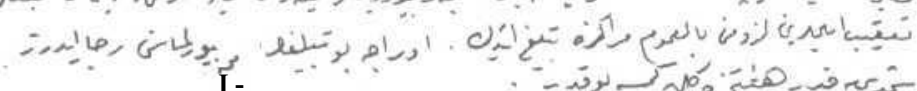

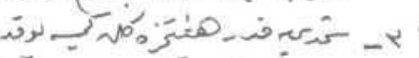

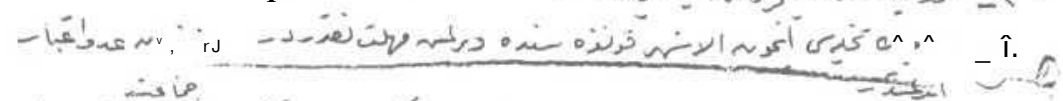

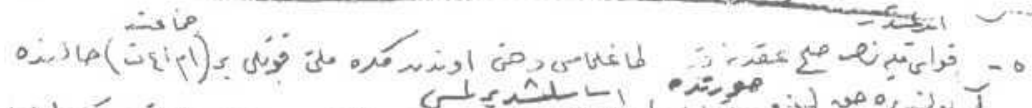

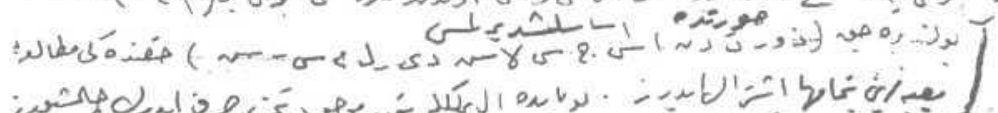
ing

uside

- S

مئ صاهر

$$
\begin{aligned}
& \text { I" } \\
& \text { I" } 20 \text { ) . . M } \\
& \text { "c. (rs, } \\
& \frac{\Delta a}{2}
\end{aligned}
$$


Amasya

Eskişehir Mutasarrıflı̆̆ı vasıtasıyla: 20. Kolordu Kumandanı 'Alî Fû"âd Pâşâ Hazretlerine

C. 17110135 ve 775 şifre ile

1- Ermenilerin mümessillere harekât-l milliye 'aleyhinde vukû'bulan mürâca 'atlarına hey'et-i temsîliye tarafindan lüzumu gibi tekzîb olunacaktır. Üçüncü Kolordu mintıkasındaki 'anâsır-ı Hristiyâniye vasıtasıyla dahî matbû'âta ve mümessillere hitaben tekzîb telgrafları yazılmiştır. Bu tedâbîrin o havalide de tatbîk ettirilmesi münâsib olur.

2- Mukabil teşkilât yapmak üzere Anadolu'ya geleceğini istihbar buyurduğunuz kimselerin ingiliz adamı olduğunu ve teşebbüslerini ta'kîb eylemelerini lüzumunu bil-'umûm merâkize teblï̆ ettik. Oraca bu tebliğin ta'mîm buyrulmasinı rica ederiz.

3- Şimdiye kadar heybetimize gelen kimse yoktur.

4- İzmir'in tahliyesi için Alaşehir Kongresi'nde verilmiş mühlet ne kadardır? Ve ne zaman 'add ü 'itibâr edilmiştir.

5-Kuvâ-yı Millîye'nin sulh 'akdine kadar dă̆glmamasl ve hatta ondan sonra milleti kuvvetli bir cemâ'at hâlinde bulunduracak surette esâslaşdırüması hakkındaki mütâla'a-i musîbelerini bi-tamâmihâ iştrâk ederiz. Bu bâbda elbirliğiyle bütün mevcudiyetimizi sarf ederek çalışlyoruzSalih Pâşâ henüz gelmedi. Takdîm-i ihtirâmâtolunur.

$18 / 10 / 35$

Vürûdu 20 minh

Mustafâ Kemâl

5. Kafkas Firkası Kumandanı

Cemîl Câhid

${ }^{9}$ TİTE Arşivi, Kutu No:309, Gömlek No:23, Belge No:23. 
MUSTAFA KEMAL PAŞA TARAFINDAN ALİ FUAD PAȘAYA

455

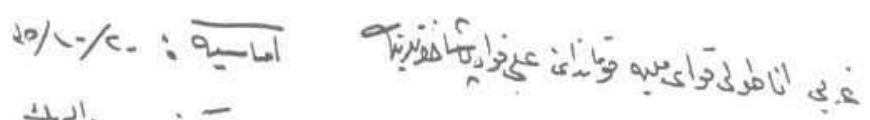

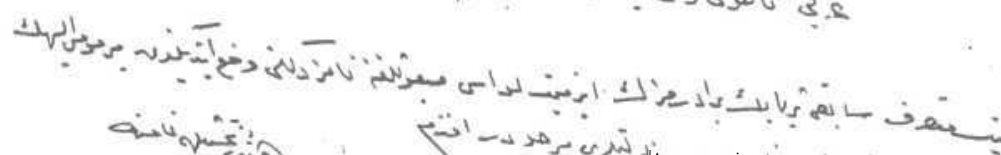

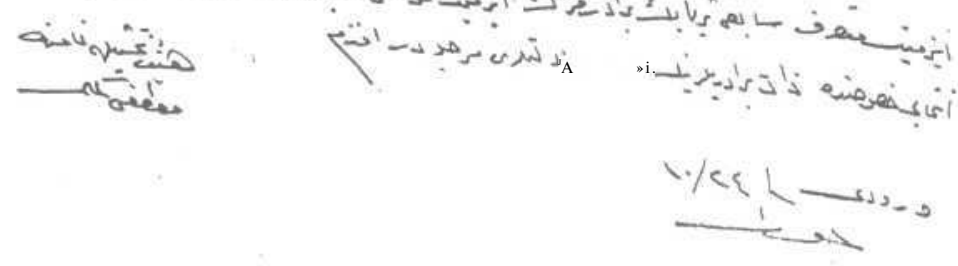


Amasya:20/10/35

Garbî Anadolu Kuvâ-yı Millîye Kumandanı 'AlîFuâdPâşâ Hazretlerine

İzmît Mutasarrıf-ı Sabıkı Süreyya Bey biraderimizin İzmît Livası meb'ûsluğuna nâmzedliğini vaz' ettiğinden mîr-i mûmâ-ileyhin intihabı husûsunda zât-ı biraderlerinin de delâletleri mercûdur. Efendim.

Vürûdu24/10

Hey"et-i Temsile Nâmina

Mustafâ Kemâl ${ }^{10}$

${ }^{13}$ TİTE Arşivi, Kutu No:309, Gömlek No:67, Belge No:67. 
ón

$$
\begin{aligned}
& 4 \\
& \text { ت }
\end{aligned}
$$

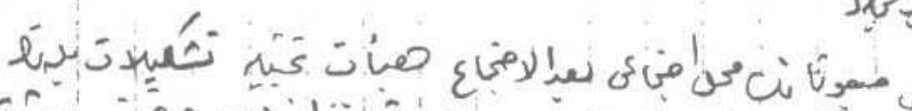

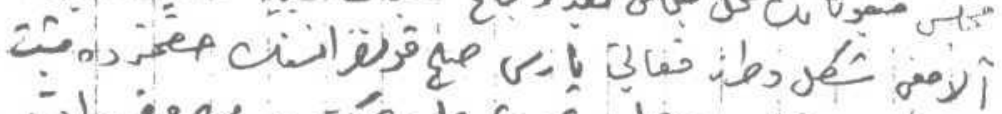

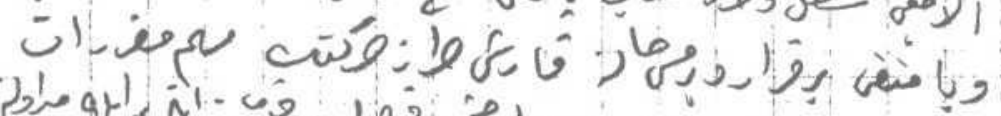

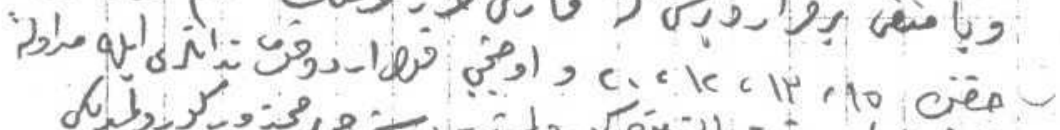

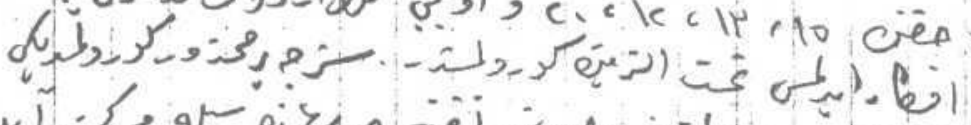

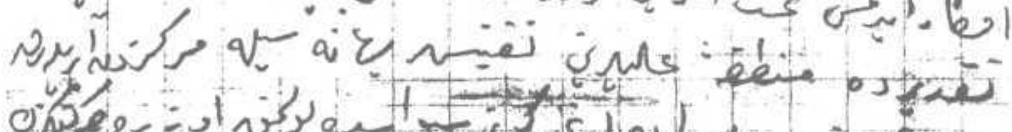

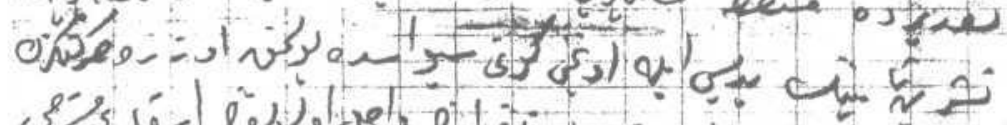

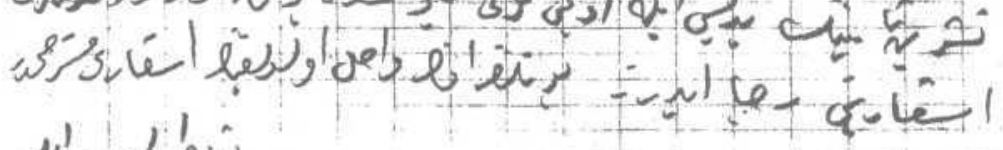

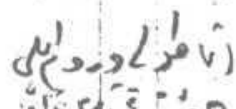

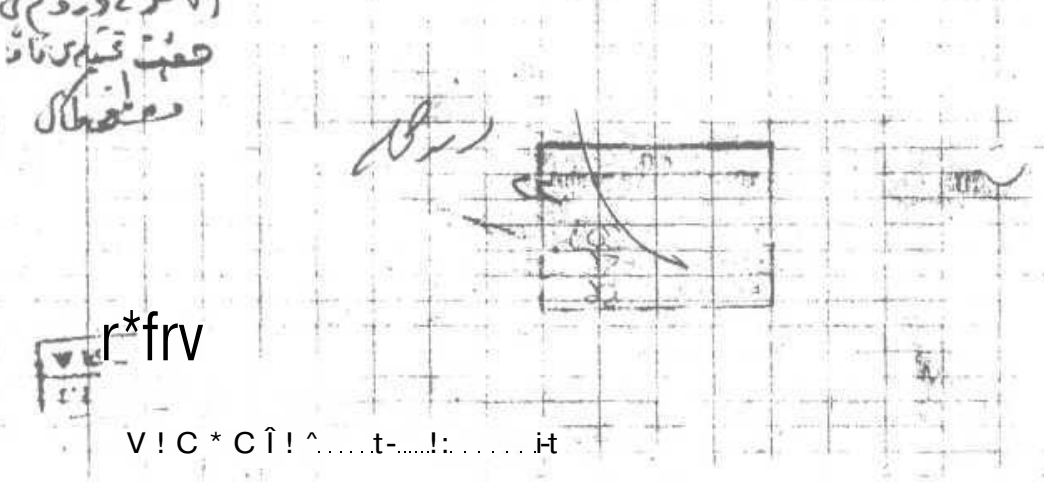


Zâta Mahsûsudur.

Gayet 'Aceledir.

'AlîFîCâd Pâsâa Hazretlerine

Meclis-i Meb'ûsânın mahal-i içtimâ'ı ba'dü'l-içtimâ' hey^et-i temsîliye teşkîlât-l milliyenin alacă̆ $l$ şekil ve tarz-l fa'âliyeti Paris Sulh Konferansı'nın hakkımızda müsbet veya menfi bir karar vermesi hâline karşı tarz-ı hareketin mühim mukarrerât hakkında 15, 13, 12, 20 ve Ǘ̧̈̈ncü Kolordu kumandanları ile müdâvele-i efkâr edilmesi taht-l elzeminde görülmüstür. Sizce bir mahzûr görülmediği takdirde mintıka-i 'âlilerini teftiş bahanesiyle merkezden ayrlarak teşrîn-i sânînin yedisi ile üçüncü günü Sivas'da bulunmak üzere hareketinizin iş'arını rica ederiz. Bu telgrafin vâsıl olduğunun iş'ân müsterhamdır.

22 Teşrîn-i Evvel

Anadolu ve Rumeli Müdâfa 'a-i HukukCem 'iyeti

Hey^et-iTemsîlesiNâmına

Mustafâ Kemâl"

${ }^{11}$ TİTE Arşivi, Kutu No:309, Gömlek No:56, Belge No:56. 